\title{
BLOOD PIGMENTS IN PERNICIOUS ANEMIA
}

\author{
By G. O. BROUN, OLIVIA AMES, SYLVIA WARREN, AND FRANCIS W. PEABODY \\ (From the Thorndike Memorial Laboratory, Boston City Hospital, and the Department of \\ Medicine, Harvard Medical School)
}

(Received for publication, November 6, 1924)

The conception of pernicious anemia as a disease associated with increased blood destruction has been widely accepted, but the problem of the mechanism involved in the destructive process has given rise to much debate. The subject demands further study and a preliminary note on one phase of the investigations going on in this laboratory has already been published (1). Phagocytosis of red cells in the bone marrow and hemolymph nodes of active cases of pernicious anemia was found to be a striking phenomenon. Observations on the blood pigments and their possible significance in relation to blood destruction will be discussed in the present communication. Particular attention has been directed to the variations in the amount of bilirubin in the blood plasma in different stages of the disease in patients who could be followed over long periods of time.

\section{METHODS AND TECHNIQUE}

Plasma bilirubin was quantitated by the method of van den Bergh and Snapper (2), an adaptation of the diazo reaction of Ehrlich. This procedure, while somewhat more laborious than the usual dilution methods, has the advantage of greater accuracy in that lipochrome, hematin, hemoglobin and alimentary lipemia do not interfere with the quantitation. The technique described by Van den Bergh and Snapper was followed closely with one exception; it was found that better results were obtained with a more concentrated diazo reagent. The reagent used in these observations was made up as follows:

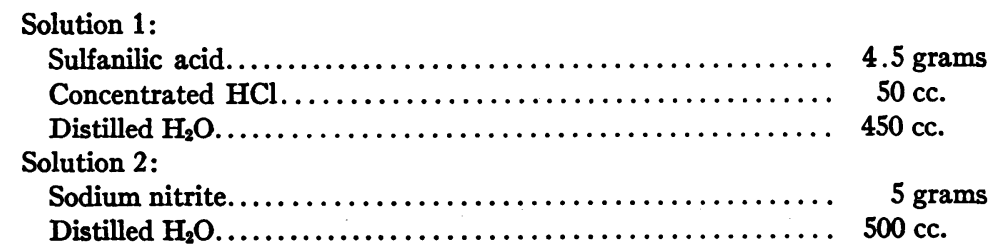


Immediately before use, one part of solution 2 is added to fifty parts of solution 1 . In addition to this reagent two other solutions are required.

Standard solution of bilirubin:

Bilirubin.................................... 025 grams

Chloroform.............................. $100 \mathrm{cc}$.

Bicarbonate alcohol solution:

$\mathrm{NaCl} \ldots \ldots \ldots \ldots \ldots \ldots \ldots \ldots \ldots \ldots \ldots \ldots \ldots, 1.5$ grams

$\mathrm{NaHCO}_{3}$ dissolved in $132 \mathrm{cc}$. distilled $\mathrm{H}_{2} \mathrm{O} \ldots \ldots \ldots \ldots \ldots \ldots . . \ldots .3$ grams

When solution is complete $368 \mathrm{cc}$. of 96 per cent alcohol is added

The quantitation is done in the following manner. Five cubic centimeters of blood are withdrawn from the patient's vein and placed in a tube containing one drop of 20 per cent potassium oxalate solution. 'The tube is corked, gently inverted several times, centrifuged, and the supernatant plasma removed. One cubic centimeter of the latter is measured into a second tube and $2 \mathrm{cc}$. of 96 per cent alcohol added. They are mixed by inversion and centrifuged for ten minutes at 2800 r.p.m. Two cubic centimeters of the supernatant fluid are then measured into a tube and $0.5 \mathrm{cc}$. of freshly prepared diazo reagent added. Finally $2.5 \mathrm{cc}$. of 96 per cent alcohol are added to the tube to clear up the fatty acid cloud. A purple color develops in the presence of bilirubin and the intensity is read in a colorimeter against the following standard:

Bicarbonate alcohol solution...........................

Standard solution of bilirubin in chloroform....................

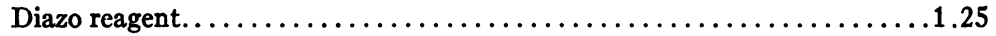

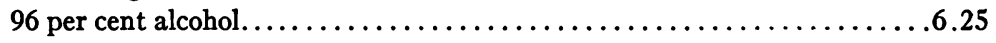

If the unknown solution be set at $10 \mathrm{~mm}$. the reading of the standard in centimeters multiplied by 1.1 gives plasma bilirubin in milligrams per $100 \mathrm{cc}$.

In addition to the quantitative method just described, van den Bergh, somewhat later (3) devised the so-called "direct" diazo reaction as a means of distinguishing jaundice due to liver injury from that associated with certain anemias and congenital hemolytic jaundice.

The test is performed as follows:

To 1 cc. of plasma are added 2 cc. of distilled water and $0.8 \mathrm{cc}$. of freshly prepared diazo reagent. The contents of the tube are at once mixed by inversion and the time of development of a distinct purple color is noted. If the purple color is seen within one minute the reaction is "prompt." If it requires more than a minute but still occurs the reaction is spoken of as "delayed." If no purple color appears the reaction is "negative." According to van den Bergh's interpretation a "prompt" reaction denotes jaundice due to liver damage, and a "delayed" reaction, jaundice due to blood destruction.

The majority of the hemoglobin determinations were made by the method of Newcomer (4). The color value of the glass standard was controlled by reading 
against it a number of specimens of blood the hemoglobin content of which had been determined by the Van Slyke (5) oxygen capacity method. The hemoglobin readings given are in terms of the Haldane scale. On this scale a hemoglobin reading of 100 per cent corresponds to an oxygen carrying capacity of $18.6 \mathrm{cc}$. and a hemoglobin content of 13.8 grams per $100 \mathrm{cc}$. of blood. Some of the earlier determinations were made by the Sahli method. Red blood cell counts were made in duplicate with Hayem's fluid as the diluting medium.

Examinations for hemoglobin and hematin in the plasma were made with a small spectroscope.

Lipochrome was extracted from the plasma by shaking with ether and this extract was used in subsequent examinations.

\section{PLASMA BILIRUBIN VALUES IN PERNICIOUS ANEMIA AND VARIOUS OTHER ANEMHAS}

Increases in the plasma bilirubin in cases of pernicious anemia have been reported by van den Bergh and other observers (6) (7). A series of such observations on 28 cases is shown in table 1. A large number of observations, made with the same technique and standards, on normal individuals and unjaundiced hospital patients have given values varying between 0.1 and $0.7 \mathrm{mg}$. of bilirubin per $100 \mathrm{cc}$. of plasma. The cases of pernicious anemia, therefore, show increases which in some cases are slight, (e.g. cases 16, 17, 20 and 22) and in other instances are well marked $(10,12,13,14,15,19,24,25,26,27$ and 28). Cases 1, 2, 3 and 6 show only moderate increases but these, at the time of observation, were clinically in a stage of remission. It is evident that there is little direct relation between the quantity of bilirubin present in the plasma and the level of the red count of different cases.

It will be noted that the direct diazo reaction is always "delayed." In no instance was a "prompt" direct diazo reaction obtained during life on a case clinically typical of pernicious anemia. Two specimens of plasma obtained several hours post mortem gave "prompt" direct reactions but a terminal liver lesion could not be definitely ruled out.

The increase in plasma bilirubin in pernicious anemia is often of diagnostic importance. Table 2 gives the findings in cases of secondary anemia due to various causes. Anemias accompanying nephritis, tuberculosis, acute or chronic hemorrhage, and malignant tumors give normal or low plasma bilirubin values except in the 
cases where there is jaundice due to a liver or bile duct lesion. In cases 40 and 41 , where carcinoma involved the bile ducts, this condition prevailed and the jaundice could easily be distinguished from that of pernicious anemia by the occurrence of a "prompt" direct reaction.

TABLE 1

Plasma bilirubin in pernicious anemia

\begin{tabular}{c|c|c|c|c}
\hline Case number & Red corpuscles & $\begin{array}{c}\text { Hemoglobin } \\
\text { (Haldane Scale) }\end{array}$ & $\begin{array}{c}\text { "Direct" diazo } \\
\text { reaction }\end{array}$ & Plasma bilirubin \\
\cline { 2 - 3 } 1 & millions per cu. mm. & per cent & & mg. per 100 cc. \\
\cline { 4 - 4 } 2 & 4.128 & 105 & Delayed & 1.1 \\
3 & 2.392 & 76 & Delayed & 0.8 \\
4 & 2.136 & 59 & Delayed & 1.0 \\
5 & 1.992 & 50 & Delayed & 2.2 \\
6 & 1.840 & 50 & Delayed & 1.2 \\
7 & 1.704 & 61 & Delayed & 1.1 \\
8 & 1.600 & 38 & Delayed & 1.8 \\
9 & 1.500 & 42 & Delayed & 2.0 \\
10 & 1.420 & 30 & Delayed & 1.7 \\
11 & 1.208 & 35 & Delayed & 2.2 \\
12 & 1.200 & 24 & Delayed & 1.5 \\
13 & 1.192 & 35 & Delayed & 2.0 \\
14 & 1.072 & 30 & Delayed & 2.3 \\
15 & 1.028 & 35 & Delayed & 2.0 \\
16 & 0.936 & 30 & Delayed & 3.3 \\
17 & 0.928 & 35 & Delayed & 1.0 \\
18 & 0.888 & 26 & Delayed & 1.0 \\
19 & 0.850 & 20 & Delayed & 1.3 \\
20 & 0.848 & 22 & Delayed & 3.4 \\
21 & 0.824 & 22 & Delayed & 1.0 \\
22 & 0.656 & 19 & Delayed & 1.9 \\
23 & 0.640 & 14 & Delayed & 1.0 \\
24 & 0.592 & 23 & Delayed & 1.9 \\
25 & 0.584 & 17 & Delayed & 2.3 \\
26 & 0.569 & 16 & Delayed & 2.5 \\
27 & 0.480 & 17 & Delayed & 4.0 \\
28 & 0.472 & 12 & Delayed & 2.8 \\
& 0.456 & 10 & Delayed & 2.5 \\
\hline
\end{tabular}

Other types of anemia, however, as shown in table 3, may give plasma bilirubin findings which are indistinguishable from pernicious anemia. Case 42, with a history suggestive of congenital hemolytic jaundice, showed a high reticulated red cell count, a marked anemia, and a plasma bilirubin distinctly above normal, which gave a "de- 
TABLE 2

Plasma bilirubin in secondary anemia

\begin{tabular}{|c|c|c|c|c|c|}
\hline $\begin{array}{c}\text { Case } \\
\text { number }\end{array}$ & $\begin{array}{c}\text { Red } \\
\text { corpuscles }\end{array}$ & $\begin{array}{c}\text { Hemo- } \\
\text { globin } \\
\text { (Haldane } \\
\text { Scale) }\end{array}$ & $\begin{array}{l}\text { "Direct" } \\
\text { diazo } \\
\text { reaction }\end{array}$ & $\begin{array}{c}\text { Plasma } \\
\text { bilirubin }\end{array}$ & Diagnosis \\
\hline & $\begin{array}{l}\text { millions } \\
\text { per cu. mm. }\end{array}$ & per cent & & $\begin{array}{l}\text { mg. per } \\
100 \text { cc. }\end{array}$ & \\
\hline 29 & 1.500 & 32 & Negative & 0 & Chronic nephritis \\
\hline 30 & 2.128 & 25 & Negative & 0 & Chronic nephritis \\
\hline 31 & 4.360 & 63 & Negative & 0.3 & Pulmonary tuberculosis \\
\hline 32 & 2.640 & 60 & Negative & 0.1 & Pulmonary tuberculosis \\
\hline 33 & 5.272 & 42 & Negative & 0.3 & Bleeding hemorrhoids \\
\hline 34 & 2.360 & 33 & Negative & 0.2 & Bleeding hemorrhoids \\
\hline 35 & 1.264 & 30 & Negative & 0.1 & Bleeding duodenal ulcer \\
\hline 36 & 3.672 & 38 & Negative & 0.1 & Banti's disease. Gastric hemorrhage \\
\hline 37 & 2.672 & 45 & Negative & 0.3 & $\begin{array}{l}\text { Primary carcinoma of kidney, with } \\
\text { liver metastases, not obstructing } \\
\text { the larger bile ducts }\end{array}$ \\
\hline 38 & 1.820 & 21 & Negative & 0.1 & Carcinoma of sigmoid \\
\hline 39 & 2.792 & 51 & Negative & 0.1 & $\begin{array}{l}\text { Rhabdomyosarcoma involving pleura, } \\
\text { pericardium and other thoracic } \\
\text { structures }\end{array}$ \\
\hline 40 & 2.880 & 25 & "Prompt" & 2.0 & $\begin{array}{l}\text { Carcinoma of stomach with liver } \\
\text { metastases }\end{array}$ \\
\hline 41 & 3.170 & 48 & "Prompt" & 9.6 & $\begin{array}{l}\text { Carcinoma of head of pancreas in- } \\
\text { volving the common bile duct }\end{array}$ \\
\hline
\end{tabular}

TABLE 3

Anemias with plasma bilirubin; findings similar to pernicious anemia

\begin{tabular}{|c|c|c|c|c|c|}
\hline $\begin{array}{c}\text { Case } \\
\text { number }\end{array}$ & $\begin{array}{c}\text { Red } \\
\text { corpuscles }\end{array}$ & $\begin{array}{c}\text { Hemo- } \\
\text { globin } \\
\text { (Haldane } \\
\text { Scale) }\end{array}$ & $\begin{array}{l}\text { "Direct" } \\
\text { diazo } \\
\text { reaction }\end{array}$ & $\begin{array}{c}\text { Plasma } \\
\text { bilirubin }\end{array}$ & Diagnosis \\
\hline & $\begin{array}{c}\text { millions } \\
\text { per cu. mm. }\end{array}$ & per cent & & $\begin{array}{l}\text { mg. per } \\
100 \mathrm{cc.}\end{array}$ & \\
\hline 42 & 2.000 & & Delayed & 2.7 & Familial hemolytic jaundice \\
\hline 43 & 1.992 & 58 & Delayed & 1.2 & Sprue \\
\hline 44 & 2.552 & 58 & Delayed & 1.3 & $\begin{array}{l}\text { Anemia following alcoholic intoxi- } \\
\text { cation }\end{array}$ \\
\hline 45 & 3.808 & 50 & Delayed & 2.0 & Lymphatic leukemia \\
\hline 46 & 2.208 & 40 & Delayed & 0.5 & Post partum anemia \\
\hline 47 & 1.174 & 24 & Delayed & 0.8 & Subacute bacterial endocarditis \\
\hline 48 & 2.690 & 49 & Delayed & 0.9 & Subacute bacterial endocarditis \\
\hline 49 & & 82 & Delayed & 1.0 & Typhoid fever \\
\hline 50 & 4.840 & 112 & Delayed & 1.1 & Lobar pneumonia \\
\hline
\end{tabular}


layed" direct diazo reaction. Case 43, of tropical sprue, contracted in the Phillipine Islands, presented a blood picture very similar to pernicious anemia and the plasma bilirubin findings are of the same type. Case 44, apparently developed an acute hemolytic anemia after an alcoholic debauch on liquor of doubtful quality. From this anemia he quickly recovered, and the blood bilirubin at the same time returned to normal limits. A case of lymphatic leukemia (no. 45) gave high blood pigments but a blood picture typical of the leukemic condition. The post-pregnancy anemia (no. 46) is listed here because, while giving normal pigment values, the case resembled pernicious anemia closely in other respects. Subacute bacterial endocarditis, typhoid fever, and pneumonia may at times give slightly increased blood bilirubin as shown in cases $47,48,49$ and 50. It should be mentioned here that some cases of pneumonia and streptococcus sepsis with jaundice, give a "prompt" direct diazo reaction. In such cases focal necrosis of the liver probably occurs as a complication. The evidence indicates, however, that anemias of the general types included in this table, while differing widely in their clinical and pathological pictures, may all be associated with an increase of blood destruction.

\section{VARIATIONS IN PLASMA BILIRUBIN AT DIFFERENT STAGES OF} PERNICIOUS ANEMIA

The chief value of the present study depends on the fact that it was possible to make numerous observations on many of the patients over long periods of time and at different stages of the disease. Repeated determinations of plasma bilirubin in individual cases of pernicious anemia show considerable fluctuations which usually bear a distinct relation to the clinical condition of the patient. The onset of a period of diarrhoea or a distinct increase in pallor and weakness are often accompanied by a rise in plasma bilirubin above the previously existing level for that patient. When followed over a period of months a certain general reciprocal relation between the bilirubin curve and that of the erythrocyte counts and hemoglobin will be seen. During periods when the red cell count and hemoglobin are decreasing, a rise in blood bilirubin is noted, while an increasing red count is usually accompanied by a return of the plasma pigment 
TABLE 4

\begin{tabular}{|c|c|c|c|c|c|}
\hline $\begin{array}{c}\text { Case } \\
\text { number }\end{array}$ & $\begin{array}{c}\text { Day of } \\
\text { observation }\end{array}$ & $\begin{array}{c}\text { Red } \\
\text { corpuscles }\end{array}$ & $\begin{array}{c}\text { Hemoglobin } \\
\text { (Haldane } \\
\text { Scale) }\end{array}$ & $\begin{array}{c}\text { Plasma } \\
\text { bilirubin }\end{array}$ & Remarks \\
\hline \multirow{5}{*}{$1\}$} & & \begin{tabular}{|c|} 
millions per \\
cu. mm.
\end{tabular} & per cont & $\begin{array}{l}\text { mg. perp } \\
100 \mathrm{cc} .\end{array}$ & \multirow{21}{*}{ Diarrhoea } \\
\hline & 1 & 4.726 & 86 & 0.9 & \\
\hline & 14 & 4.768 & 87 & 0.6 & \\
\hline & 32 & 5.592 & 102 & 0.4 & \\
\hline & 52 & 4.640 & 96 & 0.4 & \\
\hline \multirow{11}{*}{2\{} & 1 & 2.232 & 88 & 0.4 & \\
\hline & 10 & 2.520 & 89 & 0.6 & \\
\hline & 35 & 2.392 & 76 & 0.8 & \\
\hline & 49 & 2.280 & 69 & 0.6 & \\
\hline & 85 & 2.272 & 67 & 0.3 & \\
\hline & 111 & 3.088 & 90 & 0.5 & \\
\hline & 122 & 2.992 & 84 & 0.5 & \\
\hline & 136 & 3.616 & 88 & 0.3 & \\
\hline & 173 & 3.776 & 98 & 0.4 & \\
\hline & 179 & 4.088 & 97 & 0.4 & \\
\hline & 189 & 4.184 & 93 & 0.4 & \\
\hline \multirow{7}{*}{3} & 1 & 3.364 & 66 & 0.3 & \\
\hline & 8 & 3600 & 79 & 0.2 & \\
\hline & 87 & 3.552 & 64 & 0.4 & \\
\hline & 98 & 3.936 & 60 & 0.8 & \\
\hline & 143 & 3.724 & 80 & 0.6 & \\
\hline & 270 & 2.136 & 59 & 1.0 & Reticulated red corpuscles \\
\hline & & & & & per cent \\
\hline \multirow{14}{*}{63} & 1 & 1.256 & 45 & 0.8 & 2.1 \\
\hline & 3 & 0.928 & 34 & 0.8 & 0.1 \\
\hline & 15 & 0.744 & 25 & 0.8 & 0.7 \\
\hline & 25 & 1.264 & 35 & 0.6 & 0.9 \\
\hline & 36 & 1.328 & 34 & 0.7 & 4.0 \\
\hline & 44 & 1.336 & 67 & 0.6 & 3.3 \\
\hline & 57 & 1.248 & 55 & 0.5 & 3.1 \\
\hline & 63 & 0.888 & 45 & 0.4 & \\
\hline & 72 & 1.264 & 49 & 0.6 & 3.1 \\
\hline & 83 & 1.504 & 47 & 0.6 & 2.4 \\
\hline & 99 & 1.660 & 59 & 0.5 & 2.5 \\
\hline & 114 & 1.656 & 45 & 0.9 & 1.4 \\
\hline & 127 & 2.048 & 71 & 1.2 & 6.5 \\
\hline & 156 & 1.138 & 38 & 0.6 & 3.3 \\
\hline \multirow{3}{*}{15\{} & 1 & 1.624 & 46 & 1.1 & 0.2 \\
\hline & 17 & 1.464 & 46 & 1.1 & 1.2 \\
\hline & 39 & 1.448 & 40 & 1.4 & 0.8 \\
\hline
\end{tabular}

THE JOURNAL OF CLINICAL INVEETIGATION, YOL. 1, No. 3 


\begin{tabular}{|c|c|c|c|c|c|}
\hline $\begin{array}{c}\text { Case } \\
\text { number }\end{array}$ & $\begin{array}{c}\text { Day of } \\
\text { observation }\end{array}$ & $\begin{array}{c}\text { Red } \\
\text { corpuscles }\end{array}$ & $\begin{array}{c}\text { Hemoglobin } \\
\text { (Haldane } \\
\text { Scale) }\end{array}$ & $\begin{array}{c}\text { Plasma } \\
\text { bilirubin }\end{array}$ & Remarks \\
\hline \multirow{16}{*}{15} & \multicolumn{2}{|r|}{$\begin{array}{l}\text { millions per } \\
\text { cu. mm. }\end{array}$} & per cont & $\begin{array}{l}\text { mg.per } \\
100 \text { ce. }\end{array}$ & Reticulated red corpuscles \\
\hline & 54 & 1.424 & 34 & 1.4 & $\begin{array}{c}\text { per cent } \\
1.0\end{array}$ \\
\hline & 67 & 1.256 & & 2.4 & 0.6 \\
\hline & 73 & 0.920 & 28 & 2.5 & 0.2 \\
\hline & 81 & 0.952 & 23 & & 7.3 \\
\hline & 85 & 1.400 & 36 & 2.5 & 7.1 \\
\hline & 92 & 0.952 & 35 & 1.6 & 2.2 \\
\hline & 96 & 1.240 & 43 & 1.1 & 3.7 \\
\hline & 109 & 1.456 & 45 & 1.5 & 3.4 \\
\hline & 123 & 1.432 & 41 & 1.6 & 2.1 \\
\hline & 135 & 1.000 & 34 & 2.3 & 2.9 \\
\hline & 149 & 0.928 & 36 & 2.0 & 1.8 \\
\hline & 164 & 0.936 & 30 & 3.3 & 0.5 \\
\hline & 178 & 1.120 & 38 & 2.4 & 2.4 \\
\hline & 191 & 0.888 & 29 & 3.2 & 0.2 \\
\hline & 201 & 1.096 & 33 & 2.4 & 2.4 \\
\hline & 1 & 3.744 & 73 & 0.9 & \\
\hline & 34 & 4.055 & 72 & 0.9 & \\
\hline 4 & 60 & 2.808 & 60 & 1.3 & Developed lobar pneumonia \\
\hline 4 & 63 & & & 2.2 & \\
\hline & 64 & 1.992 & 50 & 1.7 & \\
\hline & 65 & 2.120 & 49 & 0.8 & Died \\
\hline & 1 & 2.040 & 44 & 0.9 & \\
\hline & 14 & 1.320 & 25 & & $\begin{array}{l}\text { Developed streptococcus hemo- } \\
\text { lyticus septicemia from acute } \\
\text { otitis media }\end{array}$ \\
\hline 11$\}$ & 15 & 1.200 & 24 & 1.5 & \\
\hline & 17 & 0.870 & 13 & 0.6 & Transfused \\
\hline & 19 & 1.171 & 26 & 1.3 & \\
\hline & 21 & 0.805 & 21 & 1.3 & Died \\
\hline & 1 & 0.848 & 22 & 3.4 & \\
\hline & 2 & & & & Transfused \\
\hline & 4 & 1.080 & 27 & 1.7 & \\
\hline & 8 & 1.104 & 24 & & Transfused \\
\hline 19\{ & 17 & 1.294 & 27 & 1.4 & \\
\hline & 19 & 1.508 & 30 & & Transfused \\
\hline & 21 & 1.640 & 35 & & \\
\hline & 31 & 1.216 & 28 & 1.1 & \\
\hline & 42 & 0.744 & 18 & 1.3 & \\
\hline
\end{tabular}


TABLE 4-Continued

\begin{tabular}{|c|c|c|c|c|c|}
\hline $\begin{array}{c}\text { Case } \\
\text { number }\end{array}$ & $\begin{array}{c}\text { Day of } \\
\text { observation }\end{array}$ & $\begin{array}{c}\text { Red } \\
\text { corpuscles }\end{array}$ & $\begin{array}{c}\text { Hemoglobin } \\
\text { (Haldane } \\
\text { Scale) }\end{array}$ & $\underset{\text { Plasma }}{\text { bilirubin }}$ & Remarks \\
\hline \multirow{14}{*}{23} & & $\begin{array}{l}\text { millions per } \\
\text { cu. mm. }\end{array}$ & per cont & $\begin{array}{l}\text { mg. per } \\
100 \mathrm{cc} .\end{array}$ & \multirow{11}{*}{ Transfused } \\
\hline & 1 & & & 1.5 & \\
\hline & 2 & 0.840 & 35 & 1.5 & \\
\hline & 10 & 0.592 & 23 & 1.9 & \\
\hline & 12 & 1.496 & 38 & 1.2 & \\
\hline & 19 & 1.304 & 43 & 1.0 & \\
\hline & 22 & 1.680 & 50 & 0.85 & \\
\hline & 33 & 1.560 & 30 & 1.0 & \\
\hline & 46 & 1.080 & 27 & 1.9 & \\
\hline & 52 & 0.956 & 25 & 1.9 & \\
\hline & 60 & 1.388 & 45 & 1.3 & \\
\hline & 1 & 0.584 & 17 & 2.3 & Transfused \\
\hline & 2 & 1.280 & 26 & & \\
\hline & 7 & 0.724 & 19 & & Transfused \\
\hline \multirow[t]{14}{*}{24} & 12 & 1.336 & 30 & 1.3 & \\
\hline & 22 & 1.152 & 34 & 0.7 & \\
\hline & 35 & 0.664 & 22 & 1.3 & Transfused \\
\hline & 47 & 1.272 & 28 & 1.2 & \\
\hline & 1 & 1.944 & 61 & 0.7 & \\
\hline & 11 & 2.296 & 78 & 0.8 & \\
\hline & 22 & 2.320 & 64 & 0.6 & \\
\hline & 48 & 0.968 & 42 & 0.8 & \\
\hline & 56 & 0.736 & 32 & 1.0 & \\
\hline & 64 & & & 1.7 & \\
\hline & 67 & 0.600 & 20 & 1.2 & \\
\hline & 70 & 0.416 & 14 & 2.8 & Transfused \\
\hline & 76 & 1.824 & 35 & 1.4 & \\
\hline & 88 & 4.000 & 79 & 0.4 & \\
\hline \multirow{12}{*}{26} & 98 & 3.288 & 69 & 0.6 & \\
\hline & 109 & 2.520 & 94 & 0.6 & \\
\hline & 117 & 2.696 & 84 & 0.6 & \\
\hline & 120 & 2.496 & 88 & 0.5 & \\
\hline & 130 & 3.504 & 67 & 0.5 & \\
\hline & 138 & 2.976 & 78 & 0.4 & \\
\hline & 151 & 2.360 & 66 & 0.4 & \\
\hline & 175 & 1.728 & 59 & 1.0 & \\
\hline & 184 & 1.408 & 37 & 1.3 & Transfused \\
\hline & 187 & 0.656 & 35 & 1.25 & \\
\hline & 198 & 0.680 & 19 & 1.20 & \\
\hline & 201 & 0.480 & 17 & 4.00 & Died \\
\hline
\end{tabular}


BLOOD PIGMENTS IN PERNICIOUS ANEMIA

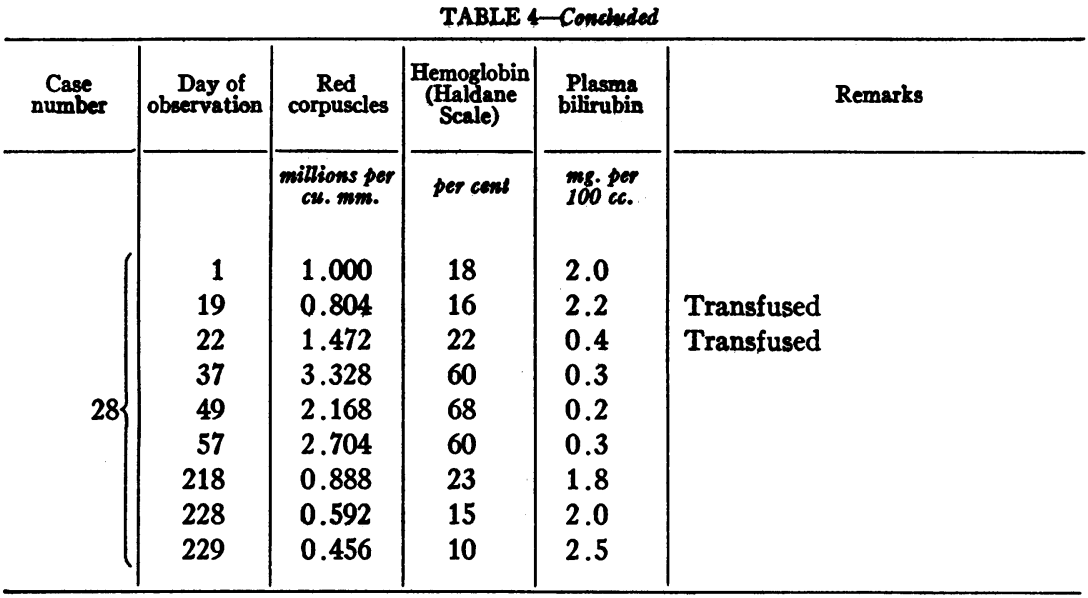
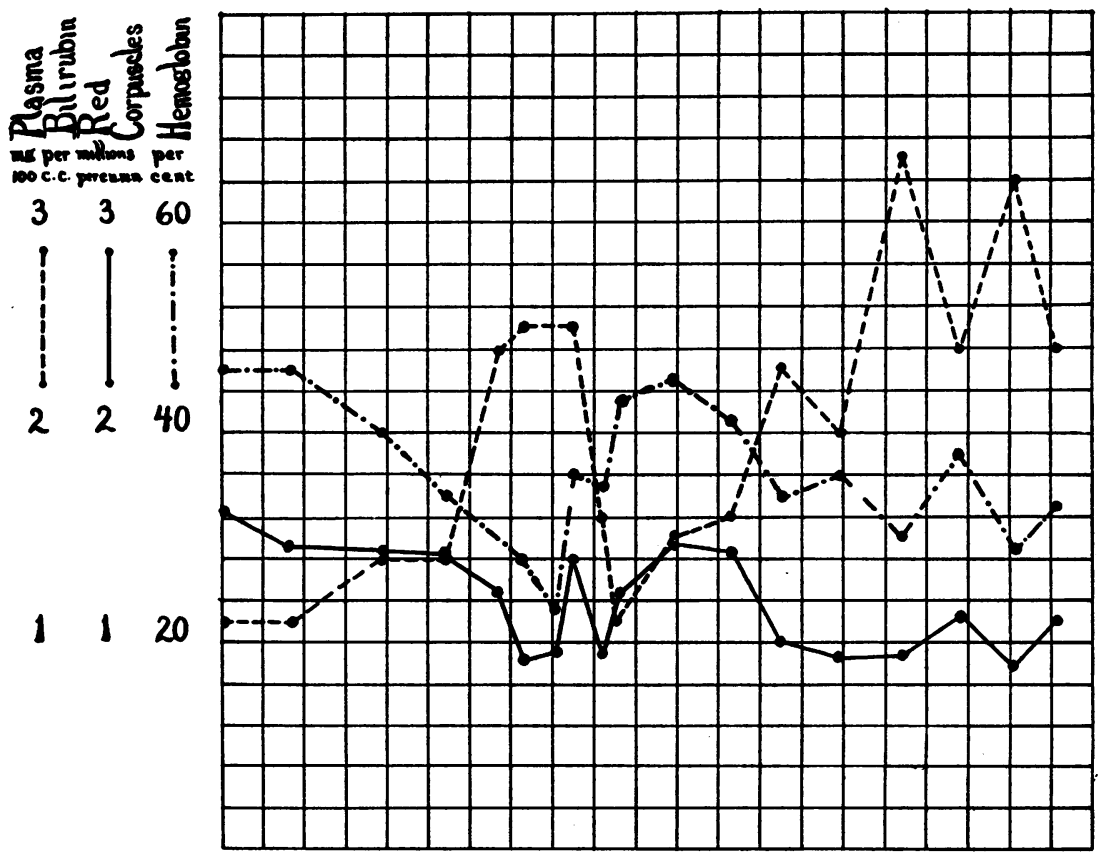

Days $\quad 10203040506070809010011012013014150160170180190200$

Fig. 1. Case 15. Variations in Plasma Bilirubin, Red Blood Corpuscles, AND HEMOGLOBIN 
to more nearly normal levels. As might be expected, occasional exceptions to this generalization are met with.

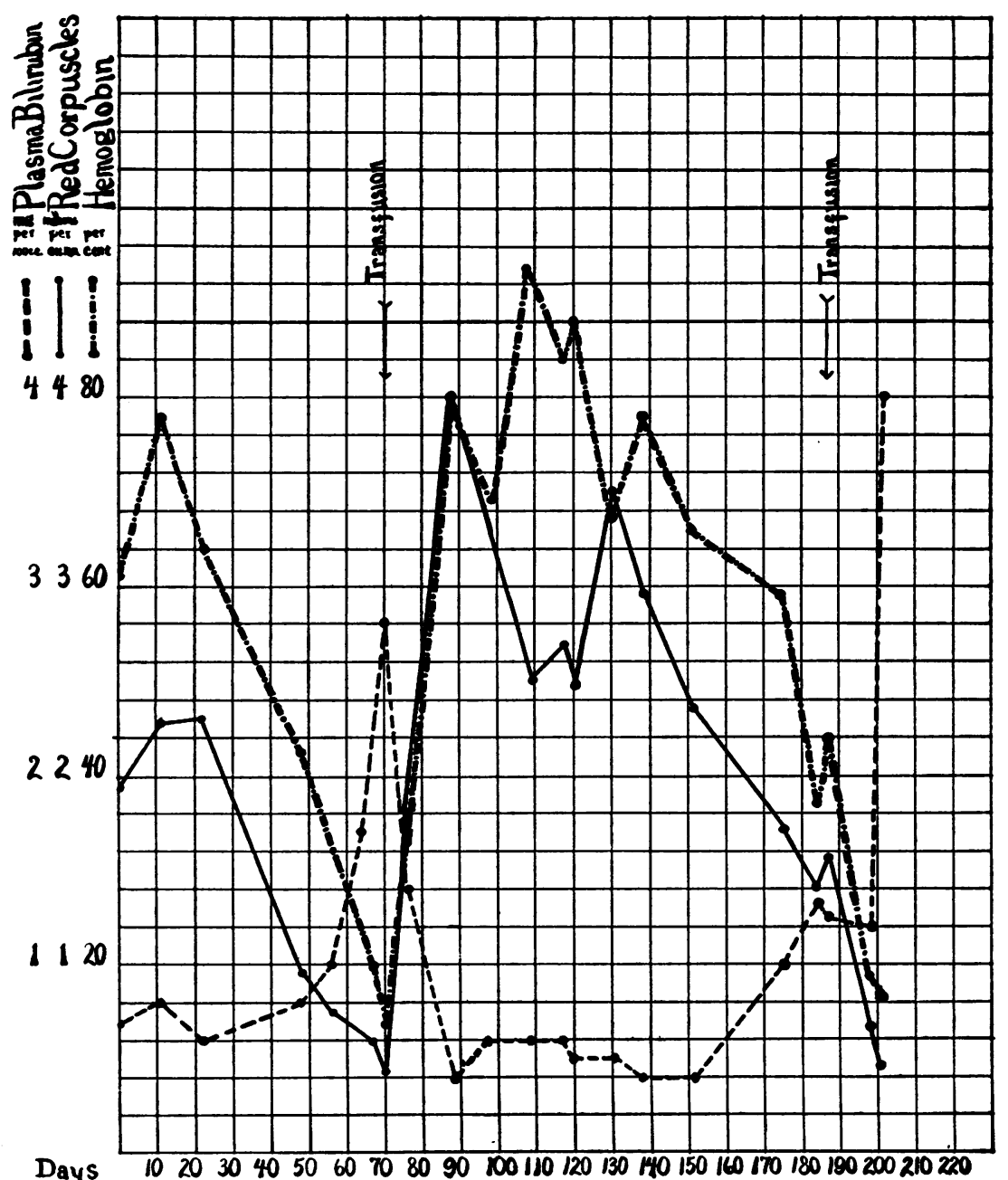

Fig. 2. Case 26. Variations in Plasma Bimirubin, Red Blood Corpuscles, AND HEMOGLOBIN

The findings in a number of typical cases are shown in the accompanying table (table 4) and charts (figs. 1, 2, 3 and 4). 
Case 1 (table 4) was at one time a severe case of pernicious anemia but has now been in remission for several years. The plasma bilirubin values are at times normal, at times slightly elevated.

Case 2 (table 4) never showed a very active hemolytic process. Neurological symptoms always predominated. A small rise in plasma bilirubin occurred at one

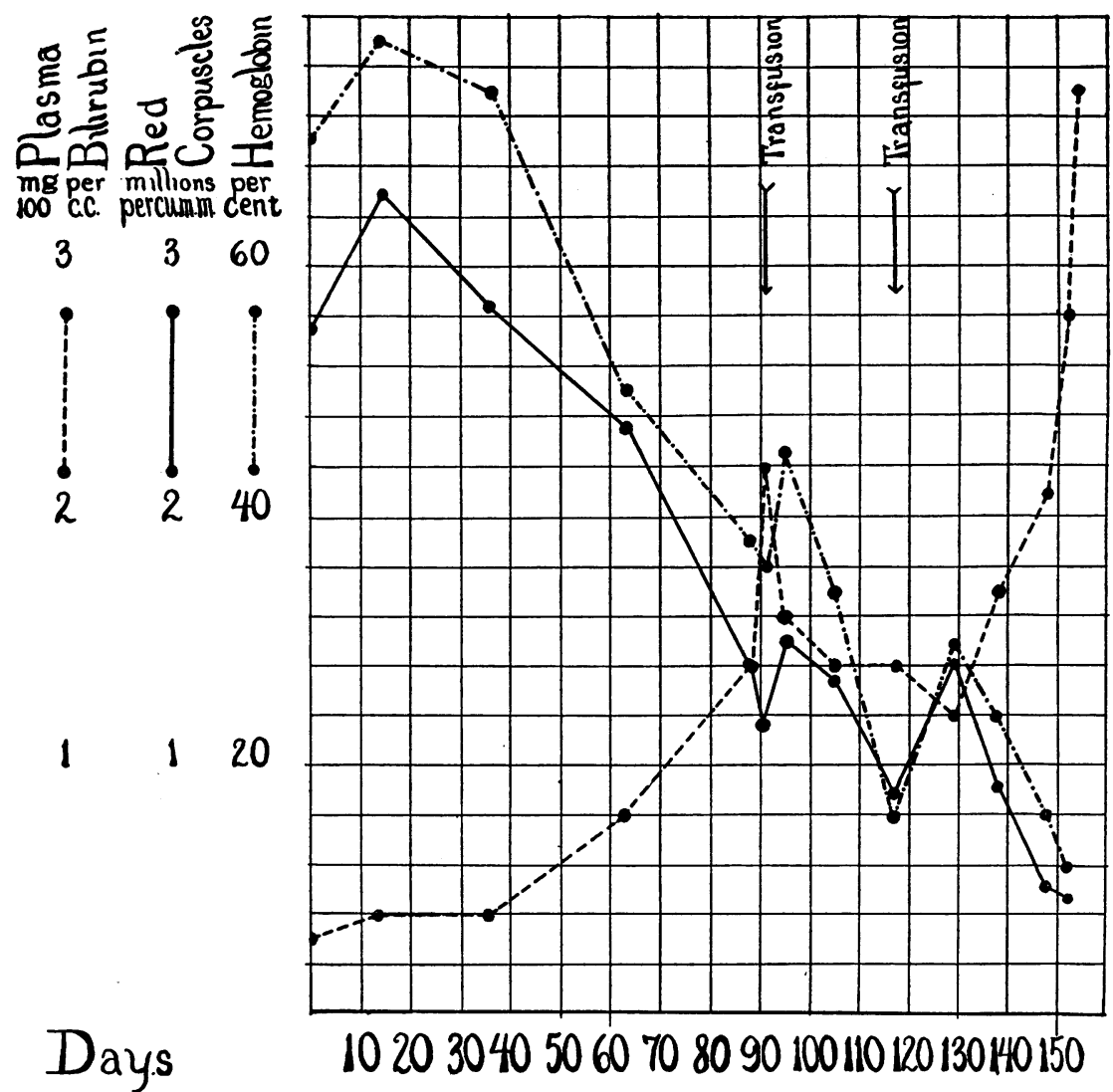

Fig. 3. Case 27. Variations in Plasma Bilirubin, Red Blood Corpuscles, AND HEMOgLOBIN

period marked clinically by severe diarrhoea, and accompanied by a very slight decrease in red count and hemoglobin. The low bilirubin value on the 85th day was indeed observed at the time when the hemoglobin was lowest, but it marked the beginning of a period of clinical improvement which has continued without interruption to the present time.

Case 3 (table 4) had suffered from a severe anemia but these observations were 
made during a period of remission. It is interesting that at times a low color index was found. The final observations seemed to indicate a return of the anemia accompanied by an increase of plasma bilirubin. The case did not return for observation after this time.

Case 6 (table 4) presents more variation from the usual trend of the curves than has any other case so far observed. He entered with a severe grade of anemia and during the period of observation went into a partial remission. On the 127th day of observation a distinct rise in pigments is noted. This occurred, contrary to the usual rule, during a period of apparent improvement. A marked rise in reticu-

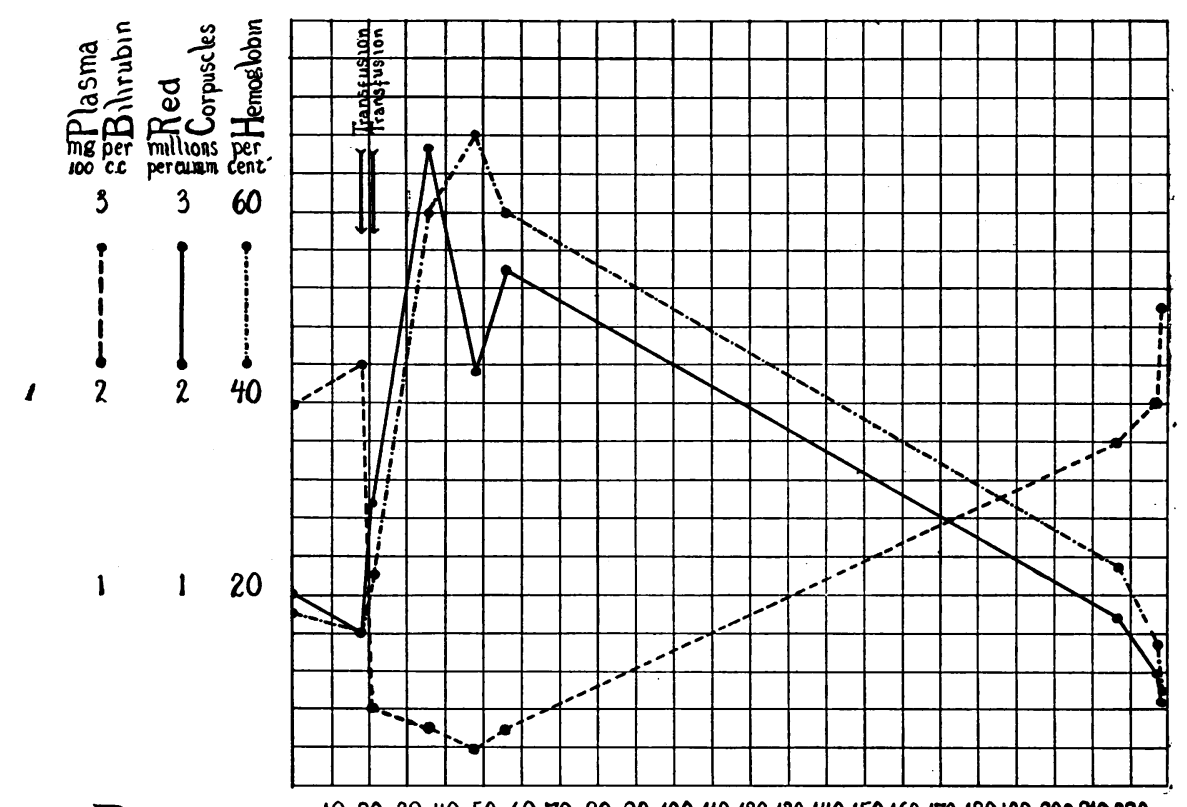

Days $\quad 10203040506070809010011012013014015016017018019020020220$

Fig. 4. Case 28. Variations in Plasma Bimirubin, Red Blood Corpuscles, AND HEMOGLOBIN

lated cells occurred at this time and it is conceivable that many of these immature cells were quickly destroyed. The patient was not in the hospital but was reporting once in two weeks as an out-patient.

Case 15 (table 4 and fig. 1) illustrates a far more active process than that observed in the four preceding cases. Here a distinct exacerbation of the anemia reduced the red cell count from $1,624,000$ to 920,000 and the hemoglobin from 46 to 23 per cent. During the same period the plasma bilirubin rose from $1.1 \mathrm{mg}$. per $100 \mathrm{cc}$. to $2.5 \mathrm{mg}$. A spontaneous remission followed during which a fall in blood bilirubin occurred. During the succeeding months the fluctuations, particularly 
in hemoglobin, are distinctly reflected in the bilirubin curve. The case has now been followed for nearly two years and general relationship between these curves has remained comparatively constant. An exception occurred on the 85th day of observation when the plasma pigment remained high although a period of regeneration had already begun. As was noted in similar circumstances in case 6 , the reticulated red cell count was quite high and the same hypothesis may be advanced, namely that the presence of immature cells in large numbers may have increased the proportion of casualties in the circulation.

\section{EFFECTS OF TRANSFUSION}

One of the interesting features of the plasma bilirubin curves is the decrease in circulating bilirubin which usually takes place after transfusion. This decrease may be immediate or may go on gradually for two weeks or more. If it fails to occur the beneficial effects of the transfusion are frequently less evident than in instances giving a distinct reduction.

In cases 19, 23 and 24 there is very little decrease in plasma bilirubin but there was a rapid disappearance of the blood given at transfusion and only slight temporary benefit was received.

Case 26 (table 4, fig. 2) is particularly striking in that it shows opposite effects after two transfusions. A transfusion on the 70th day of observation was followed by a marked remission and a fall in plasma bilirubin. The next transfusion, however, given on the 184th day, had very little clinical effect and death followed seventeen days later during a period of marked rise in the plasma bilirubin curve. Case 28 illustrates again the fall in bilirubin after a successful transfusion.

\section{EFFECT OF INTERCURRENT INFECTION}

The plasma bilirubin is often affected by the development of an intercurrent infection in a patient with pernicious anemia.

Case 4 (table 4) developed lobar pneumonia during a period of partial remission from his anemia. At the onset a sharp fall in the red corpuscle count and hemoglobin and a sharp rise in the blood bilirubin occurred. No further fall in the blood count occurred as the pneumonia progressed, and the plasma bilirubin had returned to a practically normal level at the time of death which occurred on the sixth day after pneumonia developed. 
Case 11 (table 4) developed an acute otitis media and streptococcus hemolyticus septicemia during a period in which the blood count had been rising. At the onset a marked drop in red corpuscle count and hemoglobin and a sharp rise in plasma bilirubin was found. Later, in spite of a continued change for the worse in blood condition, a decrease in plasma bilirubin occurred. At this point a transfusion was given. Very little benefit was received and there followed a distinct rise in the bilirubin curve. Death occurred a few days later from the septicemia.

TABLE 5

\begin{tabular}{|c|c|c|c|c|c|c|}
\hline \multirow{2}{*}{$\begin{array}{l}\text { Patient } \\
\text { number }\end{array}$} & 7.30 a.m. & 8.00 a.m. & $12.00 \mathrm{~m}$ & 12.30 p.m. & 4.00 p.m & \multirow{2}{*}{ Diagnosis } \\
\hline & $\begin{array}{l}\text { Plasma } \\
\text { bilirubin }\end{array}$ & & $\begin{array}{l}\text { Plasma } \\
\text { bilirubin }\end{array}$ & & $\begin{array}{l}\text { Plasma } \\
\text { bilirubin }\end{array}$ & \\
\hline & $\begin{array}{l}\text { mg.per } \\
100 \text { cc. }\end{array}$ & & $\begin{array}{l}\text { mg. per } \\
100 \text { cc. }\end{array}$ & & $\begin{array}{l}\text { mg. per } \\
100 \text { cc. }\end{array}$ & \\
\hline 50 & 0.7 & Breakfast & 0.5 & Dinner & 0.4 & Normal \\
\hline 51 & 1.0 & Breakfast & 0.7 & Dinner & 0.5 & Normal \\
\hline 52 & 0.3 & Breakfast & 0.3 & Dinner & 0.3 & Arterial hypertension \\
\hline 53 & 0.1 & Breakfast & 0.0 & Dinner & 0.0 & Arterial hypertension \\
\hline 54 & 0.7 & Breakfast & 0.4 & Dinner & 0.5 & Neuritis \\
\hline 7 & 1.4 & Breakfast & 1.3 & Dinner & 1.2 & Pernicious anemia \\
\hline 13 & 1.5 & Breakfast & 0.7 & Dinner & 1.1 & Pernicious anemia \\
\hline 15 & 2.2 & Breakfast & 2.5 & Dinner & 2.5 & Pernicious anemia \\
\hline 17 & 0.4 & & 0.5 & & 0.7 & Pernicious anemia \\
\hline 25 & 2.8 & & 2.4 & & 2.5 & Pernicious anemia \\
\hline
\end{tabular}

\section{DAILY VARIATION IN PLASMA BLLIRUBIN}

In order to gain some idea of the variation in plasma bilirubin which occurs in the course of a single day, several normal individuals and cases of pernicious anemia were examined three times in the course of a day. A regular dietary regimen was followed, which included a fairly high-fat breakfast and a fat-free meal at noon. The results obtained are listed in table 5.

The cases, with three exceptions, show a slightly higher value for the fasting specimen than for the specimens taken four and eight hours after the fat meal. While the variations during the day are in many instances well marked they are not sufficient to account for the changes which were observed at different stages of the anemia. 
The specimens included in tables $1,2,3$ and 4 were taken in the period between breakfast and dinner corresponding approximately to the second specimen of table 5 .

\section{PIGMENTS OTHER THAN BILIRUBIN IN THE PLASMA OF CASES OF PERNICIOUS ANEMIA}

Brockbank (8) has noted the constant occurrence of hemoglobin on spectroscopic examination of the plasma of cases of pernicious anemia. With this observation we are in entire accord. It is difficult to be sure that the hemoglobin present in plasma is not due to trauma in collecting blood but as the same technique was used in every instance this error is probably negligible. No effort at direct quantitation was made, but the impression was received that in general more distinct spectroscopic bands appeared during periods of clinical exacerbation than during periods of remission.

Bands of hematin were occasionally seen-an observation which van den Bergh (9) has also reported. This pigment is usually seen during periods of marked activity of the disease.

Another pigment found in severe cases during periods when the blood count was very low probably belongs to the general class of lipochromes. It is readily extracted from the plasma by ether and does not give the diazo reaction. However, on testing it with various reactions described for lutein by van den Bergh (2), entirely negative results were obtained. The exact nature of this pigment remains uncertain. It appears chiefly in severe exacerbations of anemia, particularly just before death, and it is present in large quantities post mortem.

\section{DISCUSSION}

The significance to be attached to the foregoing observations on plasma bilirubin is inevitably bound up with the question of the origin of this pigment. Stadelman (10) has held that bilirubin is produced only in the liver and that all jaundice is of hepatic origin. This theory is based on the observations of Minkowski and Naunyn (11) on hepatectomized geese. Whipple and Cowper (12) offered the first direct evidence against it by their experiments with a thoracic circulation in mammals. Mann and his co-workers (13) have proba- 
bly finally settled the point by their observations on liver ablation in dogs. A short time after complete removal of the liver their animals became as deeply jaundiced as though the common bile duct had been ligated. Jones (14) has shown the occurrence of a local increase of bilirubin in the peripheral vessels of man during an attack of paroxysmal hemoglobinuria. It has long been known that substances indistinguishable from bilirubin are found in blood extravasations into the body tissues or into the pleural or peritoneal cavities. Therefore, the evidence at present available strongly supports the view that bilirubin can be formed outside of the liver and for pigment formed in this manner the liver acts merely in an excretory capacity. The most obvious source from which this bilirubin could be derived is the hemoglobin set free in the process of red cell destruction. Whipple (15), while admitting that this process occurs, has contended that the quantity of bilirubin excreted by the liver can be altered by the type of food eaten, and that carbohydrate feeding causes an increase in bile pigment. Rous, Broun and McMaster (16), on the other hand, were unable to find any increase in bilirubin excretion on a carbohydrate diet when the entire twenty-four hour output was collected over a considerable period of time. Diets which contain bilirubin, however, do increase the amount of pigment excreted by the liver (17). Our data regarding the plasma bilirubin indicate that the pigment is usually present in greater quantity in fasting periods than during the process of absorption after meals. It seems possible, therefore, to exclude dietary factors and to assume that the plasma bilirubin was derived from hemoglobin in the process of blood destruction.

The fact that the plasma bilirubin of patients with pernicious anemia always gives a "delayed" direct diazo reaction supports the assumption that in this disease the pigment is not of hepatic origin. Hepatic diseases, and particularly those conditions causing obstruction of the larger bile ducts or extensive degeneration of the parenchyma are of course the most common causes of increased plasma bilirubin. Whenever lesions of this type are found, a "prompt" direct diazo reaction is obtained. While the chemistry underlying this reaction is not clear, the clinical value of the test has been recognized by 
several investigators (7) (18) and in our hands it has given satisfactory results in a large series of cases.

Three theories must be considered as possible explanations of the cause of the increased plasma bilirubin in pernicious anemia. First, the increase might be due to a failure of the liver to excrete the circulating bilirubin. The objections to this theory are that the output of pigment in the stools is actually increased (19) and that the estimation of liver function by the method of Rosenthal (20) gives normal results in cases of pernicious anemia. Second, a failure of the bone marrow to utilize the pigment in the formation of new red cells might also account for its accumulation in the peripheral circulation. This is extremely unlikely, however, for in secondary anemias and in definitely aplastic anemias no such accumulation of bilirubin in the plasma takes place. The third theory holds that the increase of plasma bilirubin is due to an overproduction which results from an increased rate of blood destruction. This would seem to be the best explanation of the phenomenon at present available, since it accounts for the high plasma pigments, the high stool pigments, and the rapid fluctuations in circulating red cells that are characteristic of the disease. According to this view, the liver, while capable of excreting a normal or even increased quantity of pigment, is unable to eliminate all of the bilirubin that is set free in the plasma in times of very active destruction. The observations reported in this paper extend over considerable periods of time in individual cases of pernicious anemia and the evidence they bring out is also in harmony with this explanation. Similar but less extensive observations have been reported by Gram (6). Periods marked by a falling red cell count and hemoglobin curve generally show increased blood pigment values. Periods when the blood pigments are at more nearly normal levels are usually periods of distinct clinical improvement. The occasional exceptions to this rule are in themselves enlightening. The onset of a remission marked by high reticulated red cell counts and a rising red cell and hemoglobin curve sometimes shows a high blood bilirubin level. This merely indicates that destruction and regeneration are independent processes for it is obvious that if regeneration were sufficiently active, it could counteract any amount of destruction and maintain the blood count at normal levels. This is probably what 
happens in cases of hemolytic jaundice without anemia. In pernicious anemia, on the other hand, either the factor of bone marrow exhaustion must come into play or the destructive process must exceed the margin of safety of the bone marrow.

The changes in plasma bilirubin that occur after transfusion are more difficult to explain. It is evident that immediately after transfusion the intermixture of normal plasma with that of the patient causes a dilution of the plasma bilirubin. Even granting that this occurs in every case, however, it fails to account for the marked decrease in plasma bilirubin that is sometimes seen. Neutralization of a circulating hemolysin by an antihemolysin in the transfused blood may also be suggested as a possible explanation, but the reduction in bilirubin often occurs more gradually than would be expected if this were the process at work. Moreover, case 21 received a transfusion of cells suspended in saline on the 28 th day of observation and the reduction of plasma bilirubin following this transfusion was just as great as that following two whole blood transfusions given on the 86th and 158th days respectively. If there were a circulating antihemolysin in the blood given to this patient, it must have been contained in the red corpuscles. In some cases there is a suggestion that the destructive process is actually diminished by the transfusion but in other instances the red corpuscle count and the hemoglobin curve fall rapidly after transfusion and yet the bilirubin remains at a lower level than before the transfusion. An increased utilization of pigment by the bone marrow in the formation of new erythrocytes would explain those cases which go into a distinct remission, but this theory fails to account for the instances in which the pigment decreases in spite of lack of evidence of bone marrow activity. Temporary increase in the ability of the liver to excrete pigment, owing to the improved condition of the blood, must also be taken into consideration. The level of bilirubin in the plasma is of course dependent upon the efficiency of the liver as an organ of elimination, for an organ of unlimited capacity for excretion could prevent accumulation of pigment regardless of its rate of formation. It is the balance between rate of formation and rate of excretion which determines the amount of pigment present in the plasma.

The observations on the influence of intercurrent infection on the 
plasma bilirubin in pernicious anemia are so few that they do not afford a basis for the explanation of the process at work.

The occurrence of hemoglobin and hematin in the circulating plasma indicates that all of the pigment of the destroyed cells is not broken down to the form of bilirubin before being set free in the plasma.

The nature of the ether soluble pigment present in the plasma of cases or pernicious anemia has not been determined. Its presence is a bad prognostic sign. At times it occurs in quantities equal to one-third of the dilution value of the plasma pigments. In these cases it is obviously fallacious to conclude that the dilution value represents the quantity of bilirubin present.

\section{SUMMARY}

High values for plasma bilirubin occur constantly in pernicious anemia during periods when the disease is active. They are of considerable diagnostic aid in distinguishing this disease from certain secondary anemias.

Certain cases of pneumonia, streptococcus septicemia, typhoid fever, tropical sprue, and hemolytic jaundice give plasma bilirubin findings similar to those met with in pernicious anemia.

The regular occurrence of a "delayed" direct diazo reaction in pernicious anemia serves to distinguish it from anemias associated with jaundice due to liver or bile duct lesions. In the latter conditions the plasma bilirubin gives a "prompt" direct diazo reaction.

The plasma bilirubin curve in pernicious anemia usually rises during periods of exacerbation of the clinical symptoms, and falls to more normal levels during periods of remission. This phenomenon tends to support the view that pernicious anemia is associated with increased blood destruction.

Following transfusion a reduction in the plasma bilirubin is generally observed. The explanation of this phenomenon is not clear. It would seem to be due either to a slowing of the destructive process, to an increased utilization of the pigment, or to a temporary increase in the ability of the liver to excrete pigment. Hemoglobin and hematin may occur in the plasma of cases of pernicious anemia and they are usually found in periods of clinical exacerbation of the disease. Their presence also suggests red cell destruction. 
An ether soluble pigment may also be present in the plasma of cases of pernicious anemia. When found in any considerable quantity it constitutes a serious prognostic sign. It occurs in largest amount post mortem.

\section{BIBLIOGRAPHY}

1. Peabody, F. W., and Broun, G. O. Jour. Amer. Med. Assoc., 1924, lxxxii, 963. Phagocytosis of Erythrocytes in Pernicious Anemia. A Preliminary Note.

2. van den Bergh, A. A. H., und Snapper, J. Deutsch. Arch. f. klin. Med., 1913, cx, 540. Die Farbstoffe des Blutserums.

3. van den Bergh, A. A. H. Presse méd., 1921, xxix, 441. La Recherche de la bilirubine dans le plasma sanguin par la méthode de la réaction Diazoique. Réaction prompte et réaction ralentie.

4. Newcomer, H. S. Jour. Biol. Chem., 1919, xxxvii, 465. Absorption Spectra of Acid Hematin, Oxyhemoglobin, and Carbon Monoxide Hemoglobin. A New Hemoglobinometer.

5. Van Slyke, D. D. Jour. Biol. Chem., 1918, xxxiii, 127. Gasometric Determination of the Oxygen and Hemoglobin of Blood.

6. Gram, H. C. Ugesk. f. Laeger, 1920, lexxii, 1137. Meulengracht's Plasmafarvebestemmelse.

7. Lepehne, G. Ergebn. d. inn. Med. u. Kinderh., 1921, xx, 221. Pathogenese des Ikterus.

8. Brockbank, E. M. Brit. Med. Jour., 1922, ii, 124. The Blood Serum in Pernicious Anemia. With Notes on the Nature of the Disease and Its Treatment.

9. van den Bergh, A. A. H. Der Gallenfarbstoff im Blut. Leiden, 1918, 80.

10. Stadelman, E. Der Icterus und seine verschiedenen Formen. Stuttgart, 1891, 231.

11. Minkowski, O., und Naunyn, B. Arch. f. exper. Path. u. Pharmacol., 1886, xxi, 1. Beiträge zur Pathologie der Leber und des Icterus. 2. Ueber den Icterus durch Polycholie und die vorgänge in der Leber bei demselben.

12. Whipple, G. H., and Hooper, C. W. Jour. Exper. Med., 1913, xvii, 612. Icterus. A Rapid Change of Hemoglobin to Bile Pigment in the Circulalation Outside the Liver.

13. Mann, F. C., Bollman, J. L., and Magath, T. B. Amer. Jour. Physiol., 1924, Ixviii, 114. Bilirubin Formation after Total Removal of Liver.

14. Jones, C. M., and Jones, B. B. Arch. Int. Med., 1922, xxix, 669. A Study of Hemoglobin Metabolism in Paroxysmal Hemoglobinuria; with Observations on the Extrahepatic Formation of Bile Pigments in Man.

15. Whipple, G. H. Harvey Lectures, 1921-1922, p. 95. Pigment Metabolism and Regeneration of Hemoglobin in the Body. 
16. Rous, P., Broun, G. O., and McMaster, P. D. Jour. Exper. Med., 1923, xxxvii, 421. Studies on the Total Bile. II. The Relation of Carbohydrates to the Output of Bile Pigment.

17. Broun, G. O., McMaster, P. D., and Rouse, P. Jour. Exper. Med., 1923, xxuvi, 699. Studies on the Total Bile. IV. The Enterohepatic Circulation of Bile Pigment.

18. Feigl, J., and Querner, E. Ztschr. f. d. ges. exper. Med., 1919, ix, 153. Bilirubinamie in ihren physiologisch-chemischen Beziehungen mit besonderer Berucksichtigung der diagnostischen Bedeutung.

19. Wilbur, R. L., and Addis, T. Arch. Int. Med., 1914, xiii, $235 . \quad$ Urobilin; Its Clinical Significance.

20. Rosenthal, S. M. Jour. Amer. Med. Assoc., 1922, lxxix, 2151. A New Method of Testing Liver Function with Phenoltetrachlorphthalein. III. A Clinical Report. 